\title{
RELATIONSHIP BETWEEN VITAMIN (D) LEVEL AND CARDIAC DYSFUNCTION IN HEMODIALYSIS PATIENT
}

\author{
By
${ }^{1}$ Ahmed Mahmoud Mohamed Khedr, ${ }^{1}$ Ahmed Alaa El-Din Ahmed Saad, ${ }^{2}$ Nabil Fathy Esmael Hasan, ${ }^{3}$ Mohamed Ahmed Mosaad and ${ }^{1}$ Mohamed Ahmed EI-Sayed Mohamed \\ ${ }^{1}$ Department of Internal Medicine \&Nephrology, Faculty of Medicine, Al-Azhar \\ University \\ ${ }^{2}$ Department of Clinical Pathology, Faculty of Medicine, Al-Azhar University \\ ${ }^{3}$ Department of Cardiology, Faculty of Medicine, Al-Azhar University \\ Corresponding author: Ahmed Mahmoud Mohamed Khedr, Mobile: 01097943901
}

\begin{abstract}
Background: Vitamin D deficiency has been associated with inflammation and endothelial and platelet dysfunction, which favours the risk of cardiovascular complications.

Objective: To study the correlation between serum vitamins 25(OH)-VD level and cardiac dysfunction in end stage renal disease patients on regular hemodialysis.

Patients and Methods: This was a cross-sectional study which done in Mustafa Kamel Military hospital an on 50 hemodialysis patients on regular hemodialysis for $>6$ months to assess the correlation between serum vitamin D level and cardiac dysfunction in end stage renal disease patients on hemodialysis.

Results: In our patients, we discovered that there was a highly significant relation between vit D deficiency and cardiac dysfunction in HD patients we found strong relation between Vitamin D deficiency with coronary heart disease, decrease Ejection fraction (EF\%), increase Left ventricular mass index (LVMI), End diastolic and End systolic and,Diastolic dysfunction and valvular calcification in HD patients with 25hydroxyvitamin D insufficiency and deficiency.

Conclusion: Clinical studies among patients with CKD on HD have largely that a poor vitamin D status is an independent risk factor for prevalent and incident heart disease, including coronary vascular calcification, heart failure, and CV mortality.
\end{abstract}

Keywords: Chronic kidney disease, cardiovascular, vitamin D deficiency.

\section{INTRODUCTION}

Chronic kidney disease (CKD) is a global health burden estimated to affect up to $15 \%$ of adult populations and is independently associated with increased cardiovascular (CV) disease risk similar to the risk of diabetes mellitus or coronary heart disease. This risk increases as CKD advances and is evidenced by worsening excretory function, usually manifest as declining glomerular filtration rate, and increasing proteinuria. The overall cost of CKD accounts for $1.3 \%$ of healthcare budgets of which $13 \%$ is related to the excess myocardial infarctions and strokes associated with CKD (Major et al., 2018). 
Several studies have demonstrated that individuals with CKD are at high risk of vitamin D deficiency (VDD). Gonzalez et al. (2004) reported that $97 \%$ of the patients on hemodialysis presented inadequate levels of $25(\mathrm{OH})-\mathrm{VD}$. In a cross-sectional analysis of a cohort study including 1056 United States dialysis units, Bhan et al. (2010) showed that $79 \%$ and $57 \%$ out of 908 individuals on chronic hemodialysis (HD) had 25(OH)-VD levels of $<30$ and $<20 \mathrm{ng} / \mathrm{mL}$, respectively. Hypoalbuminemia, and dialysis initiation during the winter are strong predictors of VDD, whereas VDD was universal in patients presenting with all these three predictors (Jean et al., 2017).

Vitamin D deficiency has been associated with inflammation and endothelial and platelet dysfunction, which favor the risk of cardiovascular complications (Mozos and Marginean, 2015).

1,25 $(\mathrm{OH}) 2 \mathrm{D}$ has a direct action on myocardial cells, smooth muscle fibres and vascular endothelial cells stimulating the calcium ATPase activity, promoting the calcium transfer to the intracellular space (Diaz et al., 2015).

Vitamin D appears to play a more extensive role as a cell differentiates and antiproliferative factor with actions in a variety of tissues including the renal, cardiovascular, and immune systems. As new evidence has improved our understanding of classical, as well as the non-classical, functions for vitamin $\mathrm{D}$, it has become apparent that the autocrine role of vitamin $\mathrm{D}$ is an important modulator of several systems including the immune, renal and cardiovascular systems (Umar et al., 2018).
In patients with $\mathrm{CKD}$, the new nonclassical role of vitamin $\mathrm{D}$ also encompasses regulation of the reninangiotensin system (RAS) and the nuclear factor (NF) $\kappa$ B pathway.3These emerging findings establish a new paradigm in approaching treatment to address both the classical and non-classical effects of vitamin $\mathrm{D}$ in patients affected by vitamin $\mathrm{D}$ deficiency, particularly those with CKD (Williams et al., 2009).

Emerging evidence suggests that the progression of $\mathrm{CKD}$ and many of the cardiovascular complications may be linked to hypovitaminosis D. So we will study the correlation between serum vitamin 25(OH)-VD level and cardiac dysfunction in end stage renal disease patients on regular hemodialysis.

The present study aimed to study the correlation between serum vitamin 25(OH)-VD level and cardiac dysfunction in end stage renal disease patients on regular hemodialysis.

\section{PATIENTS AND METHODS}

Our study was a cross-sectional study which was done in Mustafa Kamel Military Hospital , and conducted on 50 hemodialysis patients on regular hemodialysis for $>6$ months to asses the correlation between serum vitamin 25(OH)-VD level and cardiac dysfunction in end stage renal disease patients on hemodialysis.

A written consent was obtained from each patient and the study protocol was approved from the Medical Ethical Committee of the hospital.

Inclusion criteria: Patients $>18$ y old. Patients on hemodialysis $>6$ months. 
Exclusion criteria: Decompansated cardiac disease, severely aneamic patients $(\mathrm{Hb}<7 \mathrm{gm} / \mathrm{dL})$ patients who had any malignancy, patients on regular hemodialysis $<6$ months.

Patients were subjected to the following: History taking, Clinical examination including measurement of mean arterial blood pressure and Body Mass Index (BMI). Laboratory work-up: Blood samples were collected pre-dialysis for assessment of the following: Serum vitamin 25(OH)-VD level. Serum Creatinine, blood Urea. CBC. Fasting blood glucose. Lipid profile (serum A

Echocardiography: 2D targeted M-mode echocardiography was used to asses different cardiac parameters:

Left ventricular mass index (LVMI): $\mathrm{LVMI}(\mathrm{g} / \mathrm{m} 2)=(1.04$ [(IVST+ LVID+ PWT)3 -LVID3] -14g)/ Body surface area. According to this formula, LVMI is increased if $>134 / \mathrm{m} 2$ in men and $>110$ $\mathrm{g} / \mathrm{m} 2$ in women: End diastolic diameter (EDD). Ejection fraction (EF\%). Diastolic dysfunction. Valvular calcification. Statistics was done using SPSS program version 20 to evaluate the results.

\section{Statistically method:}

\section{The following were done:}

1. Descriptive data expressed as mean \pm standard deviation for quantitative values and as frequency and percentage for qualitative data.

2. Paired sample t-test and one way ANOVA (including post-hoc test) to perform comparison analysis of mean as regard two intervals of time or more within the same group.

$\mathrm{P}$-value $>0.05=$-significant difference (N.S).

P-value $<0.05=$ significant difference (S).

P-value $>0.01=$ highly significant difference (H.S).

3. Bivariate correlations to study the correlations between different parameters

P-value $\quad>0.05=$ Non-significant correlation.

$\mathrm{P}$-value $<0.05=$ significant correlation.

P-value $>0.01=$ highly significant correlation.

Survival analysis including Kaplan Meier test and Cox regression analysis to assess predictive effect of different factors.

\section{RESULTS}

Our sample included 50 patients diagnosed with CKD and on regular hemodialysis, sample included equal number of males and females $1: 1,58 \%$ of the sample were diagnosed with DM, while $26 \%$ were diagnosed with hypertension, and 54\% were diagnosed with ischemic heart disease (IHD). After assessment of serum vitamin D level using quantitative ELISA test, $78 \%(n=39)$ were deficient in vitamin D. Included patients had a mean BMI $25.5 \pm 0.75$, MBP $98.1 \pm$ $13.3 \mathrm{mmHg}$, and HD duration in months (mean $25.9 \pm 7.75$ months) (Table 1). 
Table (1): Demographic and clinical data of the studied groups

\begin{tabular}{|c|c|c|}
\hline Clinical data & \multicolumn{2}{|c|}{ Parameters } \\
\hline $\begin{array}{l}\text { Age (years) } \\
\text { Mean } \pm \text { SD } \\
\text { Range }\end{array}$ & \multicolumn{2}{|c|}{$\begin{array}{l}18 \pm 65 \\
25-25\end{array}$} \\
\hline & No & $\%$ \\
\hline Sex & & \\
\hline Male & 25 & 50 \\
\hline Female & 25 & 50 \\
\hline DM & 29 & 58 \\
\hline HTN & 18 & 36 \\
\hline IHD & 27 & 54 \\
\hline Prevalence of vit d deficiency & 39 & 78 \\
\hline $\begin{array}{l}\text { BMI }\left(\mathbf{k g} / \mathbf{m}^{2}\right) \\
\text { Mean } \pm \text { SD } \\
\text { Range }\end{array}$ & \multicolumn{2}{|c|}{$\begin{array}{l}25.5 \pm 0.75 \\
23.8-27.1\end{array}$} \\
\hline $\begin{array}{l}\text { MBP }(\mathbf{m m H g}) \\
\text { Mean } \pm \text { SD } \\
\text { Range }\end{array}$ & \multicolumn{2}{|c|}{$\begin{array}{c}98.1 \pm 13.26 \\
69-119\end{array}$} \\
\hline $\begin{array}{l}\text { Hemodialysis duration (months) } \\
\text { Mean } \pm \text { SD } \\
\text { Range }\end{array}$ & \multicolumn{2}{|c|}{$\begin{array}{c}25.9 \pm 7.75 \\
11-37\end{array}$} \\
\hline
\end{tabular}

Serum vitamin D level had a mean $16.8 \pm 13.16 \mathrm{IU} / \mathrm{dl}$, TLC $6.9 \pm 1.49106 / \mathrm{L}$, serum creatinine $5.4 \pm 1.07 \mathrm{mg} / \mathrm{dL}$ and blood urea $151.5 \pm 159.29 \mathrm{mg} / \mathrm{dL}$, regarding lipid profile for the included patient's serum cholesterol had a mean
$199.5 \pm 30.93 \mathrm{mg} / \mathrm{dL}$, serum triglycerides $57.2 \pm 21.19 \mathrm{mg} / \mathrm{dL}$, while CRP level was $3.2 \pm 1.07 \mathrm{mg} / \mathrm{dl}$ and finally Hemoglobin level had a mean of $12.5 \pm 6.61 \mathrm{gm} / \mathrm{dl}$. (Table 2).

Table (2): Laboratory data of the studied groups

\begin{tabular}{|l|c|c|c|}
\hline Variables & Minimum & Maximum & Mean \pm S.D. \\
\hline Serum VIT D level (IU/dl) & 5 & 45 & $16.8 \pm 13.16$ \\
\hline TLC (106/L) & 4 & 11 & $6.9 \pm 1.49$ \\
\hline Serum creatinine (mg/dl) & 3.0 & 7.0 & $5.4 \pm 1.07$ \\
\hline Blood urea (mg/dl) & 91 & 1251 & $151.5 \pm 159.29$ \\
\hline Fasting blood sugar (mg/dl) & & & \\
\hline Serum Cholesterol (mg/dl) & 147 & 256 & $199.5 \pm 30.93$ \\
\hline Serum Triglycerides (mg/dl) & 122 & 211 & $157.2 \pm 21.19$ \\
\hline CRP level (mg/dl) & 1.0 & 5.0 & $3.2 \pm 1.07$ \\
\hline HB\% (g/dl) & 11.0 & 58.0 & $12.5 \pm 6.61$ \\
\hline
\end{tabular}

All patients underwent ECHO examination, evaluations of LVMI had a mean of $130.5 \pm 37.28 \mathrm{~g} / \mathrm{m} 2$, EDD $5.8 \pm$ 1.17, EF $41.2 \pm 7.92 \%$ and valvular calcification $38 \% \quad(n=19)$, regarding diastolic dysfunction grade 1 represented $16 \%$, grade $22 \%$ and grade $350 \%$ Table (3). 
Table (3): Echocardighic data of the studied groups

\begin{tabular}{|c|c|c|c|}
\hline Echo data & \multicolumn{3}{|c|}{ Parameter } \\
\hline $\begin{array}{l}\text { LVMI (g/m2) } \\
\text { Mean } \pm \text { SD } \\
\text { Range }\end{array}$ & \multicolumn{3}{|c|}{$\begin{array}{c}130.5 \pm 37.28 \\
55-167\end{array}$} \\
\hline $\begin{array}{l}\text { EDD }(\mathbf{C m}) \\
\text { Mean } \pm \text { SD } \\
\text { Range }\end{array}$ & \multicolumn{3}{|c|}{$\begin{array}{c}5.8 \pm 1.17 \\
3-8\end{array}$} \\
\hline $\begin{array}{l}\text { EF \% } \\
\text { Mean } \pm \text { SD } \\
\text { Range }\end{array}$ & \multicolumn{3}{|c|}{$\begin{array}{c}41.2 \pm 7.92 \\
31-56\end{array}$} \\
\hline \multirow{5}{*}{ Diastolic dysfunction } & & No & $\%$ \\
\hline & No & 8 & 16 \\
\hline & Grade 1 & 11 & 22 \\
\hline & Grade 2 & 6 & 12 \\
\hline & Grade 3 & 25 & 50 \\
\hline Valvular calcification & \multicolumn{2}{|c|}{19} & 38 \\
\hline
\end{tabular}

We defined two groups based on vitamin D level, group 1 has normal vitamin D level and group 2 was vitamin D deficient. Hypertension was significantly more common in patients of group 2 with $\mathrm{p}$ value $<0.01$, moreover the prevalence of IHD was higher in group 2 with $\mathrm{p}$ value $<0.01$. In addition, MBP was significantly higher in group 1 with $\mathrm{p}$ value $<0.01$ (Table 4).

Table (4): Comparison between the two groups as regard demographic and clinical data

\begin{tabular}{|c|c|c|c|c|c|}
\hline $\begin{array}{ll}\text { Parameters } & \text { Groups }\end{array}$ & \multicolumn{2}{|c|}{ Group N 1(25) } & \multicolumn{2}{|c|}{ Group N 2(25) } & $P$ value \\
\hline \multirow[t]{2}{*}{$\begin{array}{l}\text { Age (years) } \\
\text { Mean } \pm \text { SD } \\
\text { Range }\end{array}$} & \multicolumn{2}{|c|}{$\begin{array}{l}25.3 \pm 8.25 \\
18-60\end{array}$} & \multicolumn{2}{|c|}{$\begin{array}{c}28 \pm 5.44 \\
18-65\end{array}$} & $>0.05$ \\
\hline & No & $\%$ & No & $\%$ & \\
\hline $\begin{array}{l}\text { Sex } \\
\text { Male } \\
\text { Female }\end{array}$ & $\begin{array}{l}20 \\
19\end{array}$ & $\begin{array}{l}51.3 \\
48.7\end{array}$ & $\begin{array}{l}5 \\
6\end{array}$ & $\begin{array}{l}45.5 \\
54.5\end{array}$ & $>0.5$ \\
\hline DM & 22 & 56.4 & 7 & 63.6 & $>0.05$ \\
\hline HTN & 7 & 17.9 & 11 & 100 & $<0.01$ \\
\hline IHD & 16 & 41 & 11 & 100 & $<0.01$ \\
\hline $\begin{array}{l}\mathbf{B M I}\left(\mathbf{k g} / \mathbf{m}^{\mathbf{2}}\right) \\
\text { Mean } \pm \mathrm{SD} \\
\text { Range }\end{array}$ & \multicolumn{2}{|c|}{$\begin{array}{l}25.6 \pm 0.81 \\
23.8-27.1\end{array}$} & \multicolumn{2}{|c|}{$\begin{array}{l}25.5 \pm 0.51 \\
24.8-26.5\end{array}$} & $>0.05$ \\
\hline $\begin{array}{l}\text { MBP }(\mathbf{m m H g}) \\
\text { Mean } \pm \text { SD } \\
\text { Range }\end{array}$ & \multicolumn{2}{|c|}{$\begin{array}{c}100.7 \pm 13.66 \\
69-119\end{array}$} & \multicolumn{2}{|c|}{$\begin{array}{c}89.1 \pm 6.12 \\
79-99\end{array}$} & $<0.01$ \\
\hline $\begin{array}{l}\text { Hemodialysis duration } \\
\text { (months) } \\
\text { Mean } \pm \text { SD } \\
\text { Range }\end{array}$ & \multicolumn{2}{|c|}{$\begin{array}{l}25.3 \pm 8.25 \\
11-37\end{array}$} & \multicolumn{2}{|c|}{$\begin{array}{c}28 \pm 5.44 \\
19-36\end{array}$} & $>0.05$ \\
\hline
\end{tabular}


Regarding laboratory tests of both groups, there was no significant difference between both groups in terms of TLC, serum cholesterol level, serum triglycerides and CRP levels (Table 5).

Table (5): Comparison between the two groups as regard laboratory data

\begin{tabular}{|c|c|c|c|}
\hline $\begin{array}{ll}\text { Parameters } & \text { Groups } \\
\end{array}$ & Group 1 & Group 2 & $P$ value \\
\hline $\begin{array}{l}\text { TLC (106/L) } \\
\text { Mean } \pm \text { SD } \\
\text { Range }\end{array}$ & $\begin{array}{l}6.9 \pm 1.48 \\
5-11\end{array}$ & $\begin{array}{c}6.7 \pm 1.62 \\
14-9 \\
\end{array}$ & 0.711 \\
\hline $\begin{array}{l}\text { Serum Cholesterol }(\mathbf{m g} / \mathbf{d l}) \\
\text { Mean } \pm \text { SD } \\
\text { Range }\end{array}$ & $\begin{array}{c}202.1 \pm 33.62 \\
147-256\end{array}$ & $\begin{array}{c}190.3 \pm 16.55 \\
168-217\end{array}$ & 0.425 \\
\hline $\begin{array}{l}\text { Serum Triglycerides }(\mathbf{m g} / \mathbf{d l}) \\
\text { Mean } \pm \text { SD } \\
\text { Range }\end{array}$ & $\begin{array}{c}155.7 \pm 22.16 \\
122-211 \\
\end{array}$ & $\begin{array}{c}162.6 \pm 17.21 \\
131-189 \\
\end{array}$ & 0.181 \\
\hline $\begin{array}{l}\text { CRP level (mg/dl) } \\
\text { Mean } \pm S D \\
\text { Range }\end{array}$ & $\begin{array}{c}3.1 \pm 1.19 \\
1-5\end{array}$ & $\begin{array}{l}3.5 \pm 3.91 \\
2-5\end{array}$ & 0.192 \\
\hline
\end{tabular}

Regarding ECHO parameters, groups 1 had significantly higher LVMI with $\mathrm{p}$ value <0.01, higher EDD p (value <0.01). While EF was significantly higher in group 2 with normal vitamin $\mathrm{D}$ level $\mathrm{p}$ value $<0.01$.
Diastolic dysfunction was more frequent in group 1 with low vitamin D levels with $\mathrm{p}$ value $<0.01$, also valvular calcification was higher in group 1 with $\mathrm{p}$ value $<0.01$ (Table 6).

Table (6): Comparison between the two groups as regard echocardiographic data

\begin{tabular}{|c|c|c|c|c|c|c|}
\hline$\underbrace{\text { Groups }}_{\text {Parameters }}$ & & \multicolumn{2}{|c|}{ Group 1} & \multicolumn{2}{|c|}{ Group 2} & $P$ value \\
\hline $\begin{array}{c}\text { LVMI }(\mathbf{g} / \mathbf{m} 2) \\
\text { Mean } \pm \text { SD } \\
\text { Range }\end{array}$ & & \multicolumn{2}{|c|}{$\begin{array}{c}149.3 \pm 11.85 \\
128-167\end{array}$} & \multicolumn{2}{|c|}{$\begin{array}{c}64.1 \pm 7.27 \\
55-76\end{array}$} & $<0.01$ \\
\hline $\begin{array}{c}\text { EDD }(\mathbf{C m}) \\
\text { Mean } \pm \text { SD } \\
\text { Range } \\
\end{array}$ & & \multicolumn{2}{|c|}{$\begin{array}{c}6.3 \pm 0.79 \\
5-8\end{array}$} & \multicolumn{2}{|c|}{$\begin{array}{c}4.2 \pm 0.75 \\
3-5\end{array}$} & $<0.01$ \\
\hline $\begin{array}{c}\text { EF \% } \\
\text { Mean } \pm \text { SD } \\
\text { Range }\end{array}$ & & \multicolumn{2}{|c|}{$\begin{array}{c}37.7 \pm 4.62 \\
31-49\end{array}$} & \multicolumn{2}{|c|}{$\begin{array}{c}53.8 \pm 1.89 \\
51-56\end{array}$} & $<0.01$ \\
\hline \multirow{5}{*}{$\begin{array}{l}\text { Diastolic } \\
\text { dysfunction }\end{array}$} & & No & $\%$ & No & $\%$ & \multirow{5}{*}{$<0.01$} \\
\hline & No & 1 & 2.6 & 7 & $63.6 \%$ & \\
\hline & Grade 1 & 7 & $17.9 \%$ & 4 & $36.4 \%$ & \\
\hline & Grade 2 & 6 & $15.4 \%$ & 0 & $0 \%$ & \\
\hline & Grade 3 & 25 & $64.1 \%$ & 0 & $0 \%$ & \\
\hline $\begin{array}{c}\text { Valvular } \\
\text { calcification }\end{array}$ & & 10 & 25.6 & 9 & 81.8 & $<0.01$ \\
\hline
\end{tabular}


Using a linear regression model for multivariate analysis, serum vitamin D level was significantly correlated to MBP with $\mathrm{p}$ value $<0.01$, negative correlation indicted that with vitamin $\mathrm{D}$ increase MBP drops. Blood urea was significantly correlated to vitamin D level; positive correlation was found between high levels of vitamin $\mathrm{D}$ and blood urea level $\mathrm{p}$ value 0.015 .

Regarding cardiac functions, LVMI was significantly correlated to vitamin D level with $\mathrm{p}$ value $<0.01$, there was a strong negative correlation between vitamin $\mathrm{D}$ level and LVMI $\mathrm{R}=-0.95$. As well as EDD which also reveal a strong positive correlations with serum vitamin $D$ level with $p$ value $<0.01$.

Finally, left ventricular function $(\mathrm{EF})$ was significantly correlated to serum vitamin $\mathrm{D}$ level with $\mathrm{p}$ value $<0.01$, it demonstrate a strongly positive correlations $\mathrm{R}=0.93$ (Table 7).

Table (7): Linear regression model showing correlation between vitamin D level with demographics and clinical data

\begin{tabular}{|c|c|c|}
\hline \multicolumn{2}{|l|}{ Clinical data } & Serum VIT D level (IU/dl) \\
\hline \multirow{2}{*}{ Age (years) } & $\mathrm{R}$ & 0.016 \\
\hline & p-value & 0.914 \\
\hline \multirow{2}{*}{ BMI (Kg/M2) } & $\mathrm{R}$ & -0.025 \\
\hline & p-value & 0.865 \\
\hline \multirow{2}{*}{ MBP (mmHg) } & $\mathrm{R}$ & $-0.409^{* *}$ \\
\hline & $\mathrm{p}$-value & $<0.01$ \\
\hline \multirow{2}{*}{ Hemodialysis duration (months) } & $\mathrm{R}$ & 0.228 \\
\hline & p-value & 0.112 \\
\hline \multirow{2}{*}{ Serum VIT D level (IU/dl) } & $\mathrm{R}$ & \\
\hline & p-value & \\
\hline \multirow{2}{*}{ TLC (106/L) } & $\mathrm{R}$ & -0.051 \\
\hline & p-value & 0.727 \\
\hline \multirow{2}{*}{ Serum creatinine (mg/dl) } & $\mathrm{R}$ & 0.070 \\
\hline & $\mathrm{p}$-value & 0.628 \\
\hline \multirow{2}{*}{ Blood urea (mg/dl) } & $\mathrm{R}$ & $0.341^{*}$ \\
\hline & $\mathrm{p}$-value & 0.015 \\
\hline \multirow{2}{*}{ Fasting blood sugar (mg/dl) } & $\mathrm{R}$ & -0.087 \\
\hline & p-value & 0.550 \\
\hline \multirow{2}{*}{ Serum Cholesterol (mg/dl) } & $\mathrm{R}$ & -0.139 \\
\hline & $\mathrm{p}$-value & 0.334 \\
\hline \multirow{2}{*}{ Serum Triglycerides (mg/dl) } & $\mathrm{R}$ & 0.113 \\
\hline & p-value & 0.434 \\
\hline \multirow{2}{*}{ CRP level (mg/dl) } & $\mathrm{R}$ & 0.276 \\
\hline & p-value & 0.052 \\
\hline \multirow{2}{*}{$\mathrm{HB} \%(\mathrm{~g} / \mathrm{dl})$} & $\mathrm{R}$ & 0.279 \\
\hline & p-value & 0.050 \\
\hline \multirow{2}{*}{ LVMI (g/m2) } & $\mathrm{R}$ & $-0.958^{* *}$ \\
\hline & $\mathrm{p}$-value & $<0.01$ \\
\hline \multirow{2}{*}{ EDD $(\mathbf{C m})$} & $\mathrm{R}$ & $-0.809^{* *}$ \\
\hline & p-value & $<0.01$ \\
\hline \multirow{2}{*}{ EF \% } & $\mathrm{R}$ & $0.931^{* *}$ \\
\hline & $p$-value & $<0.01$ \\
\hline
\end{tabular}




\section{DISCUSSION}

In patients suffering from chronic kidney disease (CKD), the prevalence of cardiovascular disease is much more common than in the general population (Toussaint et al., 2017).

Their high morbidity and mortality cannot be explained by traditional cardiovascular risk factors, such as advanced age, the presence of diabetes, hypertension, hypertriglyceridemia and low levels of high-density lipoprotein (HDL) cholesterol.

According to studies, also abnormalities of calcium, phosphorus, vitamin D, and parathyroid hormone $(\mathrm{PTH})$ are associated with the occurrence of cardiovascular disease (Fanari et al., 2015).

Some of them also indicate a relationship between vitamin D deficiency and hypertension, insulin resistance, diabetes, and dyslipidaemia (Zheng et al., 2013).

Vitamin D deficiency has been associated with numerous events and conditions in the general population such as falls, fractures, diabetes, autoimmune diseases, cardiovascular and renal diseases, tuberculosis, depression, neurodegenerative diseases, and cancer (Holick, 2007).

Vitamin D deficiency is present even in the early stages of chronic kidney disease. Numerous observational studies have confirmed low levels of both total 25-hydroxyvitamin D 25(OH)D which enables the assessment of the adequacy of vitamin $\mathrm{D}$ stores) and 1,25dihydroxyvitamin D $(1,25(\mathrm{OH}) 2 \mathrm{D}-$ biologically active form of vitamin $\mathrm{D}$ ), in patients with CKD and end-stage renal disease (ESRD) (Wang et al., 2014).

Clinical studies among patients with CKD have largely shown that a poor vitamin $\mathrm{D}$ status is an independent risk factor for prevalent and incident heart disease, including coronary vascular calcification, heart failure, and CV mortality (Toussaint et al., 2017).

The role of vitamin D deficiency had been underestimated until a significant association was found between vitamin D therapy and survival benefit in haemodialysis patients. Theoretically age may be a risk factor for atherosclerosis and cardiac dysfunction, however in our study there was no significant difference between the two groups. This result is in an agreement with Beaulieu et al. (2017) who found no significant effect of age on cardiac function in hemodialysis patients.

As regard sex, there was no significant difference between the two groups. This result is in disagreement with Masengu et al. (2016) who found a significant effect of sex on cardiac function in hemodialysis patients as males are more susceptible than females.

In our study, there was no significant difference between the two groups as regard BMI. This result is in agreement with Voorzaat et al (2017) who found no significant effect of BMI on cardiac function in hemodialysis patients.

In our study, there was no significant difference between the two groups as regard DM. This result is in disagreement with Yan et al. (2018) who found a significant effect of DM on cardiac function in hemodialysis patients. 
As regard HTN, there was no significant difference between the two groups. This result is in disagreement with Bashar et al. (2015) who found a significant effect of HTN on cardiac function in hemodialysis patients.

End stage renal disease patients are characterized by dyslipidaemia which contributes for inflammation and diffuse atherosclerosis.

In our study, there was no significant difference between the two groups as regard cholesterol and TG levels. This result is in agreement with Siddiqui et al. (2018) who found no significant effect of cholesterol and TG on cardiac function in hemodialysis patients. However, as regard LDL and HDL, there was a significant difference between the two groups. This result is in agreement with Kirkpantur et al. (2008) who found a significant effect of LDL and HDL on cardiac function in hemodialysis patients.

As regard fasting blood sugar, there was no significant difference between the two groups. This result is in an agreement with Yan et al. (2018) who found no significant effect of fasting blood sugar on cardiac function in hemodialysis patients.

In our patients, we discovered that there was a highly significant difference between the two groups as regard vit D deficiency and cardiac dysfunction in HD patients This result is in an agreement with Gluba-Brzózka et al. (2018) we found strong relation between Vitamin D deficiency with coronary heart disease, Ejection fraction (EF\%), Left ventricular mass index (LVMI), End diastolic and End systolic diameters, Diastolic function and Valvular calcification in HD patients with 25-hydroxyvitamin D insufficiency.

\section{CONCLUSION}

Clinical studies among patients with CKD on HD have largely that a poor vitamin $\mathrm{D}$ status is an independent risk factor for prevalent and incident heart disease, including coronary vascular calcification, heart failure, and CV mortality.

\section{REFERENCES}

1. Bashar K, Zafar A, Elsheikh S, Healy DA, Clarke-Moloney M, Casserly L, Burke PE, Kavanagh EG and Walsh SR (2015): Predictive parameters of arteriovenous fistula functional maturation in a population of patients with end-stage renal disease. PloS one ,10(3): e0119958.

2. Beaulieu MC, Dumaine CS, Romann A and Kiaii $M$ (2017): Advanced age is not a barrier to creating a functional arteriovenous fistula: a retrospective study. The Journal of Vascular Access ,18(4):307-12.

3. Bhan I, Burnett-Bowie SAM, Ye J, Tonelli $M$ and Thadhani $R$ (2010): Clinical measures identify vitamin D deficiency in dialysis. Clin. J. Am. Soc. Nephrol , 5:460467.

4. Diaz BG, Guizzardi S and de Talamoni NT (2015): Molecular aspects of intestinal calcium absorption. World Journal of Gastroenterology: WJG, 21(23):7142.

5. Fanari $Z$, Hammami $S$ and Hammami MB, Hammami S and Abdellatif A (2015): Vitamin D deficiency plays an important role in cardiac disease and affects patient outcome: Still a myth or a fact that needs exploration? J. Saudi Heart Assoc., 27:264271.

6. Franca Gois PH, Wolly M, Ranganathan $D$ and Seguro AC (2018): Vit D deficiency in chronic kidney disease:Recent evidence and controversie. International Journal of environmental Research and Puplic Health,15(8) :1773-125.

7. Gluba-Brzózka A, Franczyk B, Ciałkowska-Rysz A, Olszewski $R$ and Rysz J (2018): Impact of vitamin $D$ on the 
cardiovascular system in advanced chronic kidney disease (CKD) and dialysis patients. Nutrients, 10(6):709-135.

8. Jean G, Souberbielle JC and Chazot C (2017): Vitamin D in chronic kidney disease and dialysis patients. Nutrients.9: 328-265.

9. Major RW, Cheng MRI, Grant RA, Shantikumar S, Xu G and Oozeerally I. (2018): Cardiovascular disease risk factors in chronic kidney disease: A systematic review and metaanalysis. PLoS ONE, 13(3): e0192895.

10. Masengu A, Maxwell AP and Hanko JB (2016): Investigating clinical predictors of arteriovenous fistula functional patency in a European cohort. Clin Kidney J., 9:142-147.

11. Mozos I and Marginean O (2015): Links between vitamin D deficiency and cardiovascular diseases. BioMed Research International, 9: 1-13.

12. Siddiqui MA, Ashraff S, Santos D, Rush R, Carline $T$ and Raza $Z$ (2018): Predictive parameters of arteriovenous fistula maturation in patients with end-stage renal disease. Kidney Research and Clinical Practice. 357:266-277.

13. Toussaint A, Löwe B, Brähler $E$ and Jordan P (2017): The Somatic Symptom Disorder-B Criteria Scale (SSD-12): factorial structure, validity and population-based norms. Journal of Psychosomatic Research, 97:9-17.

14. Umar M, Sastry KS and Chouchane AI (2018): Role of vitamin $\mathrm{D}$ beyond the skeletal function: a review of the molecular and clinical studies. International Journal of Molecular Sciences, 19(16) :1618-176.
15. Voorzaat BM, van Schaik J, Crobach SL, van Rijswijk CS and Rotmans JI (2017): Alpha-1 antitrypsin deficiency presenting with MPO-ANCA associated vasculitis and aortic dissection. Case Reports in Medicine, $1-5$.

16. Wang AYM, Fang F, Chan J, Wen YY, Qing S, Chan IHS, Lo G, Lai KN, Lo WK and Lam CWK, (2014): Effect of paricalcitol on left ventricular mass and function in CKD - The OPERA trial. J. Am. Soc. Nephrol, 25:175-186.

17. Yan Y, Ye D, Yang L, Ye W, Zhan D, Zhang L, Xiao J, Zeng $Y$ and Chen Q (2018): A meta-analysis of the association between diabetic patients and AVF failure in dialysis. Renal Failure. 40(1):379-83.

18. Zheng CM, Chiu YP ,Hou YC, Liu YM Wu MS,Lin YF,Lo YL,Lu KC ,Hsu YH and Wang YH (2020): Influence of intradialytic systole blood pressure changes on arteriovenous accsess thrombosis in maintenance hemodialysis patients .International Jouranl of Clincal Practice, el 13799-135.

19. Zheng Z, Shi H, Jia J and D: Lin S (2013): Vitamin D supplementation and mortality risk in chronic kidney disease: A metaanalysis of 20 observational studies. BMC Nephrol , 14(2): 199-134. 
در اسة العلاقه بين مستوي فيتامين (د) وقصور وظائف القلب

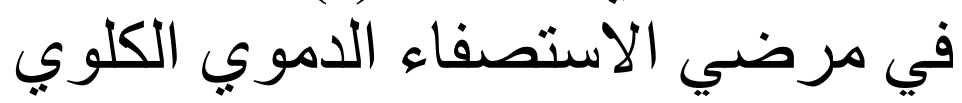

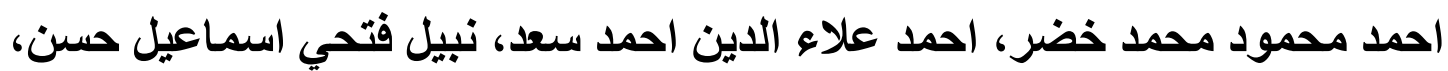
محمد احمد مسعد، محمد احمد السيا احمد

الامراض الباطنيه و الكلى، الباثولوجيا الاكلينيكيه، كلية الطب، جامعة الازهر

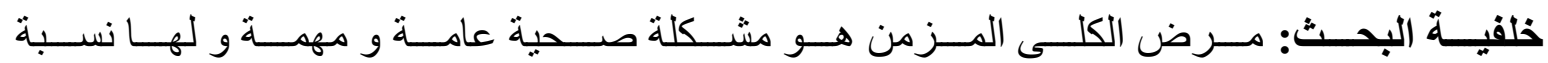

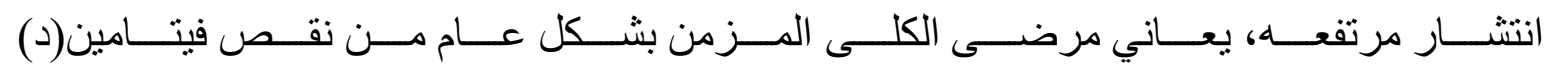

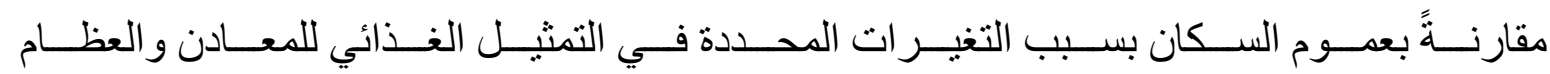

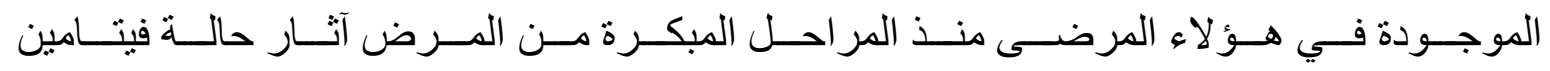

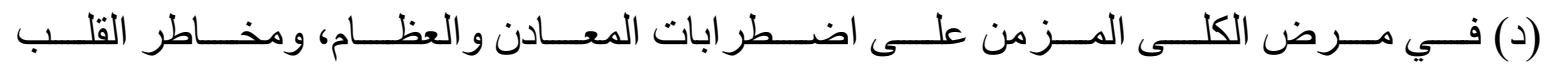

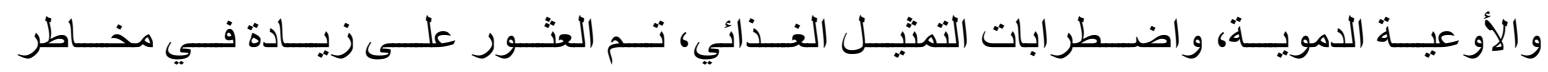
الإصابة بأمر اض القلب والأو عية الدموية، في وجود نقص فئات فلئامين د.

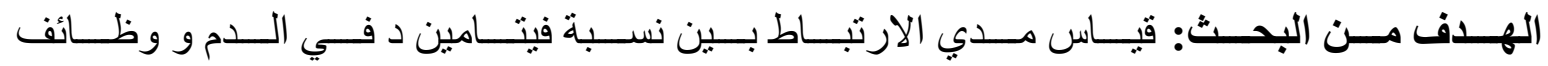
القلب.

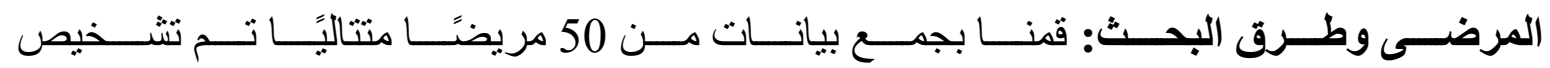

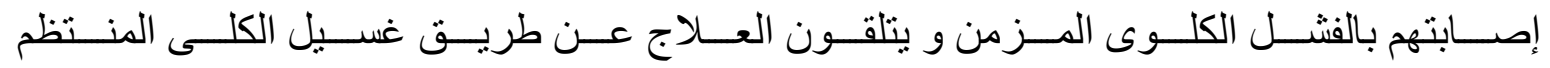

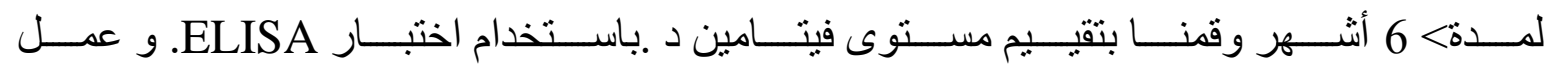

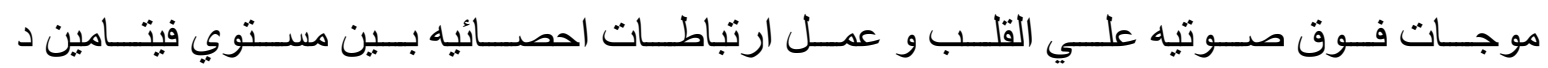
و و وظائف القلب.

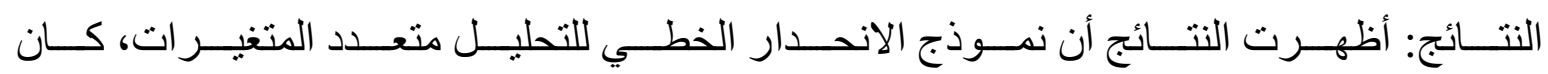

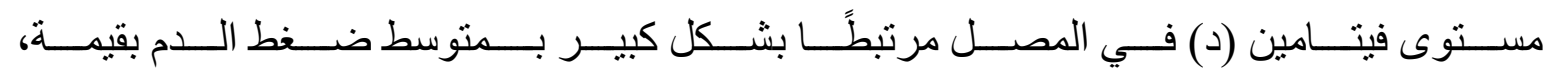

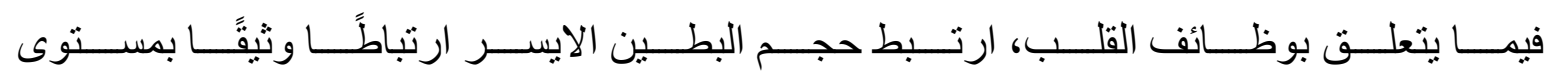

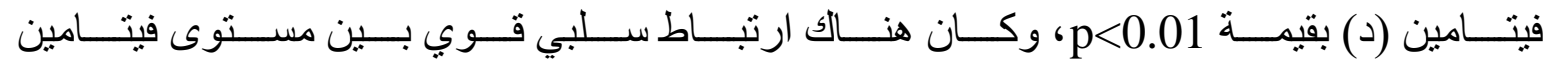

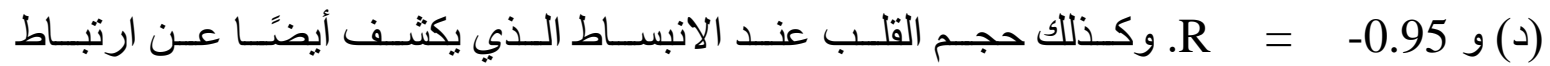

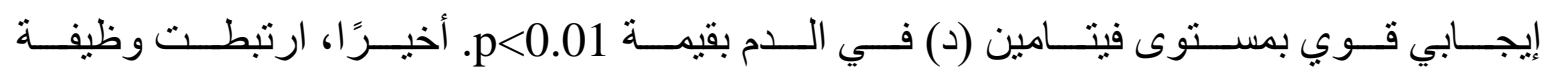




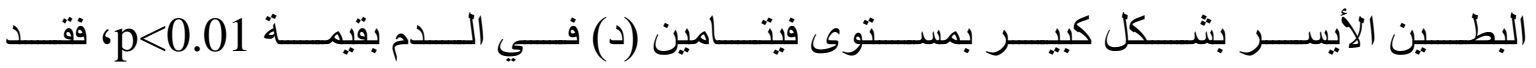
أظهرت ارتباطًا إيجابيًا قويًا ل0.

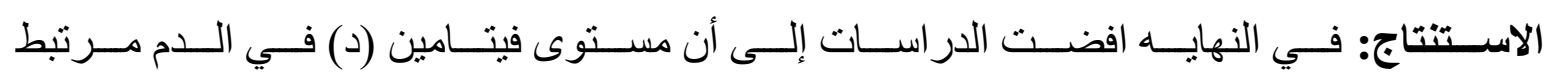

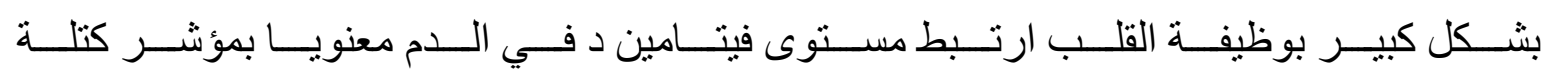

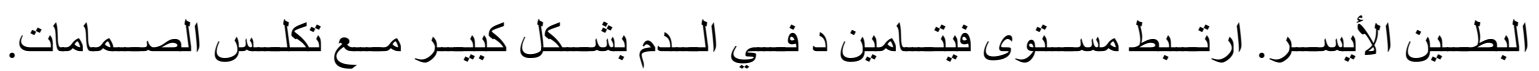
ارتبط مستوى فيتامين (د) في الدم بشكل كبير مع الخلل الانبساطي. الكلمات الداله:نقص فيتامين د، الفثل الكلوي المزمن، اعتلال القلب. 